\title{
Fiscaoeconomia
}

Journal Homepage: dergipark.gov.tr/fsecon

\section{Testing the Slippery Slope Framework in the Scope of Fiscal Sociology: A Study on the Classification of Income Levels ${ }^{1}$}

Rana DAYIOĞLU ERUL ${ }^{2}$

Article Info

Article History:

Date Submitted: 21.11.2019

Date Accepted: 08.01.2020

Jel Classification:

$H 26, K 34, Z 13$

Keywords:

Slippery Slope Framework, Fiscal Sociology,

Tax Compliance,

Socio-Economic Variables.
Abstract

The purpose of the study is testing the hypothesis of the slippery slope framework which is "power of authorities and trust in authorities explain tax compliance". Trust in authorities and power of authorities are the two main variables of the theory and in this study, other social, cultural and economic variables that affect tax compliance are included to measure the effects of socio economic variables on tax compliance. In the study, the countries are classified according to their income levels and the data for the period 2007-2017 are analyzed by panel data method. As a result, research suggests that power of authorities and trust in authorities have the most significant impact on tax compliance and additionally the study finds evidence for the assumptions of the slippery slope framework.

\section{Introduction}

Fiscal sociology is the sociological analysis of taxes and public expenditures by the point of the view of its economic, institutional, cultural, political, and historical aspects. It basically covers examining financial events from a sociological point of view, investigating the effects of financial events on society on the one hand and the effects of social structure and developments on financial events on the other.

It is useful to take into consideration the elements shaping the social structure when putting into practice tax policies. Therefore, it is easy to adopt the policies by the society and reach their success. With this perspective as a starting point, the aim of this study is to examine the importance of the regulations based on fiscal sociology in the context of the slippery slope framework and discuss the extent the arguments of the slippery slope framework are effective in policy determination.

\section{Fiscal Sociology and the Slippery Slope Framework}

\footnotetext{
${ }^{1}$ This study is carried out within the scope of the research support given by TUBITAK (The Scientific and Technological Research Council of Turkey).

${ }^{2}$ Dr., University of Exeter, Tax Administration Research Centre, m.r.erul@exeter.ac.uk
} 


\subsection{Definition and Importance of Fiscal Sociology}

Fiscal sociology is a field of science which suggests to combine many research areas such as economy, culture, law, politics, history and etc. The main difference is this conjunction of different areas. In other words, while other areas of social sciences deal with an only specific area, fiscal sociology examines many branches of science and makes research by depending on the relations of these. This integrative and unifying feature of financial sociology welcomes to many disciplines such as economic sociology, state sociology, anthropology, political science, financial law and public law, as well as the need to address different dimensions such as social geography, local economy and regional development (Brun, 2013:11).

The main characteristic of fiscal sociology is its focus on political, economic, cultural, institutional, and historical influences on taxation and public expenditures (Campbell, 1993:164). However, fiscal sociology should above all be concerned with the articulation between state and society with the combination of history and three large tasks are involved (Padgett, 1981:76);

- An institutional analysis of the structure of governmental expenditure and/or taxation policymaking, along with a historical description of its operation and development,

- A "symptomatic" analysis of mechanisms for the representation of external group and/or class interests within the system,

- A "causal" analysis of the impact of expenditure and taxation policies on a wide variety of social phenomena such as economic growth, income distribution, the regulation of economic relations and the changing structure of the policy itself.

\subsection{The Slippery Slope Framework}

Kirchler, Hoelzl and Wahl (2008) differentiated between voluntary and enforced tax compliance based on the criteria of trust in the authorities and the power of authority in their study. In this study, trust in the authority is defined as the group and individual perception that the tax administration works to be helpful towards a common goal. On the other hand, the power of authority is the taxpayer's perceptions of the tax administration's potential and capability to 
detect and sanction tax evasion - for example, through frequent tax audits (Kirchler, Hoelzl and Wahl, 2008:212).

Figure 1. Slippery Slope Framework Tax Compliance Model

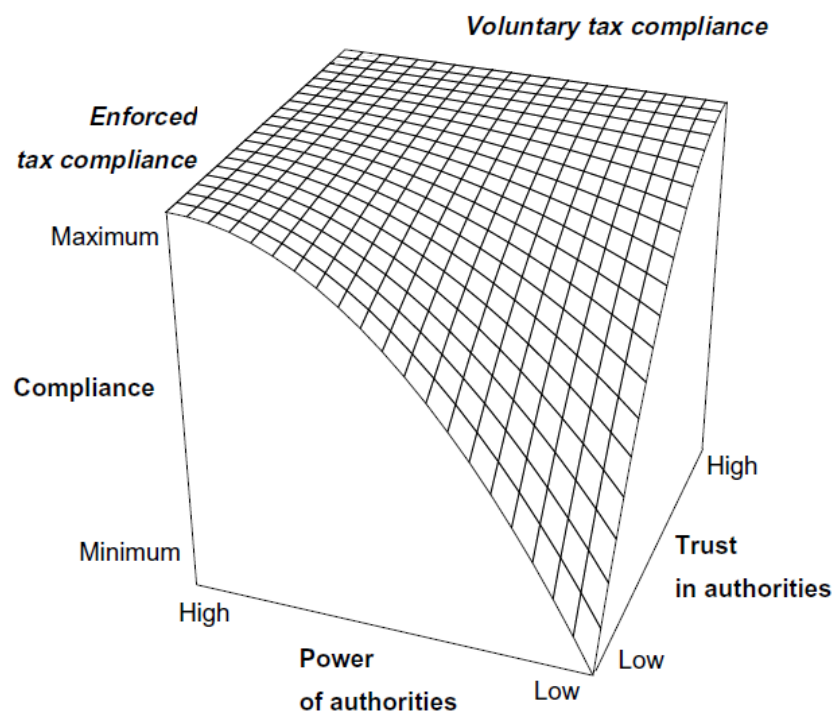

Source: Kirchler et al., 2008:212.

In the slippery slope tax compliance model, tax compliance is influenced by both the trust in the authorities and the power of authority. According to this, tax compliance will be low when both the power of the authorities and trust in them are at low levels. However, if an atmosphere of trust and cooperation can be established between the parties, then trust in the authority, thus voluntary tax compliance will be high.

The powerful is the authority, there will be a high level of compulsory tax compliance. However, as some practices of the tax administration may lead the taxpayer to a slippery slope, steering them to tax evasion, it is necessary to increase the voluntary tax compliance by creating mutual trust in the relations with the taxpayer (Saruç, 2015:60). In this respect, in the model, the power of the authority brings more compulsory tax compliance, whereas the trust in the authority implies voluntary tax compliance.

Towards these explanations about the model, the basic assumption of the slippery slope hypothesis is that "trust in the authority and the power of the authority explain the level of tax compliance." 


\subsection{The Relation Between Fiscal Sociology and the Slippery Slope Framework}

As the tax system and policies of each country reflect the characteristics of the country's social, political, cultural and economic structure, the tax systems differ according to the characteristics of the social structure. Tax systems that are in line with the social structure ensure that tax compliance is achieved at a high level. The importance of fiscal sociology occurs at this point because by the application of fiscal sociology arrangements and policies that are appropriate to the structure of the society and which are in harmony with the values, traditions and understandings of the society is easily accepted by the society.

The slippery slope framework is one of the tax compliance models and psychological and behavioral models among these. This means that tax psychology and tax sociology are important values for the model and it affects tax compliance by the variables of these two concepts. In this respect, the slippery slope framework has the significance with the connection to fiscal sociology by tax compliance.

As the main determinants of the slippery slope framework are trust in the authority and the power of the authority, these variables are formed by the structure of the society. Because psychological and sociological background influence trust in the authority and the power of the authority, this means that sociological research, namely fiscal sociology, takes important role for the model of the slippery slope framework.

\section{Determinants of Tax Compliance}

Tax compliance means individuals or institutions act in accordance with the spirit and practice of the law without any need for enforcement (James and Alley, 2004:32). Another definition of tax compliance suggests that taxpayers prepare and submit their statements in accordance with the tax laws, regulations, and judicial decisions in force in the country (Roth et al., 1989:21). The determinants of tax compliance are important in determining the variables to be used in the analyses to be applied in this research. Tax behaviour is strongly related to economic and psychological factors depending on tax compliance theories. Tax policies ought to be designed with considering the factors which all affect the tax system institutionally or individually. That's why it is essential to evaluate all behaviour determinants and in this section, these determinant will be examined in the framework of tax compliance theories. 


\subsection{Classical Determinants}

Allingham and Sandmo (1972) were the first authors to examine tax evasion decision using the economic model, and the literature on the subject started with their study and later their model was developed by many authors. The expected benefit model of Allingham and Sandmo suggests that the variables that determine tax compliance are tax control, tax penalties, risk of getting caught and punished, tax rate and income (expected benefit) ${ }^{3}$.

According to this theory, the tax declaration decision is a decision under uncertainty; the reason for this is that failure to report one's full income to the tax authorities does not automatically provoke a reaction in the form of a penalty and in this way, the taxpayer has the choice between two main strategies (Allingham and Sandmo, 1972:324): First, he may declare his actual income and second, he may declare less than his actual income. If he chooses the latter strategy his payoff will depend on whether or not he is investigated by the tax authorities. If he is not, he is clearly better off than under strategy; if he is, he is worse off. The choice of a strategy is therefore a non-trivial one.

In the expected benefit model the taxpayer should pay a penalty rate on the undeclared income and this assumption leads to the conclusion that when the tax rate increases there will be two opposing effects, an income and a substitution effect (Yitzhaki, 1974:201). In the study of Yitzhaki, he shows that assuming that the taxpayer has an absolute risk aversion which decreases with income, it can concluded that as the tax rate increases the income evaded decreases and in this case there is no substitution effect (Yitzhaki, 1974:201). Thus, according to the model, Yitzhaki concludes that increasing tax rates will reduce unreported income, a prediction that contradicts general belief (Saruc, 2015:46).

The expected benefit model and the Yitzhaki model were then extended by sociological factors. In the study conducted by Juan, Lasheras and Mayo (1994), sociological variables which affect tax compliance but not concluded in these two models such as taxpayer's age, level of education, being selfish or altruistic, social pressure on tax evasion, taxpayer's perception of tax burden injustice and social or professional group's tax evasion tendency are included in the research (Batırel, 1996:54).

\footnotetext{
${ }^{3}$ For detailed information see Allingham, M. G. and Sandmo, A. (1972), "Income Tax Evasion: A Theoretical Analysis". Journal of Public Economics, 1, 323-338.
} 


\subsection{Psychological and Behavioral Determinants}

Despite the development of economic models in tax compliance and the factors affecting tax compliance, the models focusing on the psychological and social aspects of tax compliance have started to be developed due to insufficient economic elements in explaining tax compliance. The most widely known and applied of these is prospect theory and this theory was developed by Kahneman and Tversky (1979).

In prospect theory, utility function is determined according to the perception level of losses and gains. Individuals determine a reference point and then evaluate their losses and gains according to this reference point and the reference point determined is usually the initial wealth value of individuals (Kahneman and Tversky, 1979:286). Since the value function is defined as deviations from the reference point, what is important here is how individuals perceive these changes that occur at the reference point (Kahneman and Tversky, 1979:279).

In prospect theory; not only the maximization of individual interest and individual benefit function that determines the tax payment preferences of individuals, but also psychological perception determines taxpayers' attitudes and behaviors about tax payment. In this respect, prospect theory, contrary to the expected benefit model, only deals with psychological factors, but not economic factors and suggests that the main determinants of tax compliance are psychological, cultural, moral, legal, religious, institutional, and political elements and costs rather than economic factors.

According to another model which is developed by Song and Yarbrough in 1978, three determinants such as legal environment, tax ethics, opportunity and other situational factors affect tax compliance (Song and Yarbrough, 1978:444). Kirchler, Hoelzl and Wahl (2008) differentiated between voluntary and enforced tax compliance based on the criteria of trust in the authorities and the power of authority in their study. In the slippery slope tax compliance model, tax compliance is influenced by both the trust in the authorities and the power of authority. According to this, tax compliance will be low when both the power of the authorities and trust in them are at low levels. However, if an atmosphere of trust and cooperation can be established between the parties, then trust in the authority, thus voluntary tax compliance will be high (Kirchler, Hoelzl and Wahl, 2008:212). 


\subsection{Other Determinants}

Among the researches in line with the new approach of fiscal sociology developed in the 2000's bring up the themes of sociological sensitivity in tax policy approach, the relations between micro and macro issues, the relations between constitutional issues and fiscal sociology and the place of bureaucratic regulations in financial issues (McLure, 2003:6-7). The new fiscal sociology approach includes interdisciplinary relationships of the fields such as economics, political science, law, history, and public policy in addition to sociology (Martin et al., 2009:2) and focuses on facts that can be measured at the level of society rather than the individual. Some recent reports by the OECD (OECD, 2004; OECD, 2014) suggest that economic factors, as well as external factors such as social perceptions, international changes, media and social changes have an impact on tax compliance and clearly indicate sociological variables among the factors with an effect on tax compliance. OECD made a classification about the determinants of tax compliance and there are five categories as business profile, industry, sociological factors, economic factors and psychological factors ${ }^{4}$. This shows that in addition to economic and psychological factors, sociological factors should be taken into consideration while measuring the effects of tax compliance.

In Figure 2, the behaviour of taxpayers can be seen in groups. The main or determinants of tax compliance and tax behaviour are shown in grey, the grey boxes indicate classical tax behaviour determinants such as penalty, audit, income depending economic models and theories. Remaining indicators are grouped in three categories, their relation is demonstrated by the connecting lines.

Determinants shown in the figure include all the elements affecting tax compliance according to tax compliance theories. These elements consist of economic variables (tax rate, penalty, audit, income, costs, distribution of tax revenues, benefits from public goods), social variables (tax morale, beliefs and attitudes as part of psychological factors, social norms, cultural norms, education, legal regulations, interaction between tax authority and taxpayers). Since these variables are shaped within the framework of socio-economic structure, sociological researchsociety structure-fiscal sociology takes an important role for tax compliance.

\footnotetext{
${ }^{4}$ For detailed information see OECD, 2004:40.
} 
Figure 2. Main Determinants of Tax Compliance

\section{Tax Authority}

\begin{tabular}{|c|}
\hline Business ethics \\
\hline Use of tax money \\
\hline Responsive regulation \\
\hline Trust \\
\hline Transparency \\
\hline Fairness \\
\hline
\end{tabular}

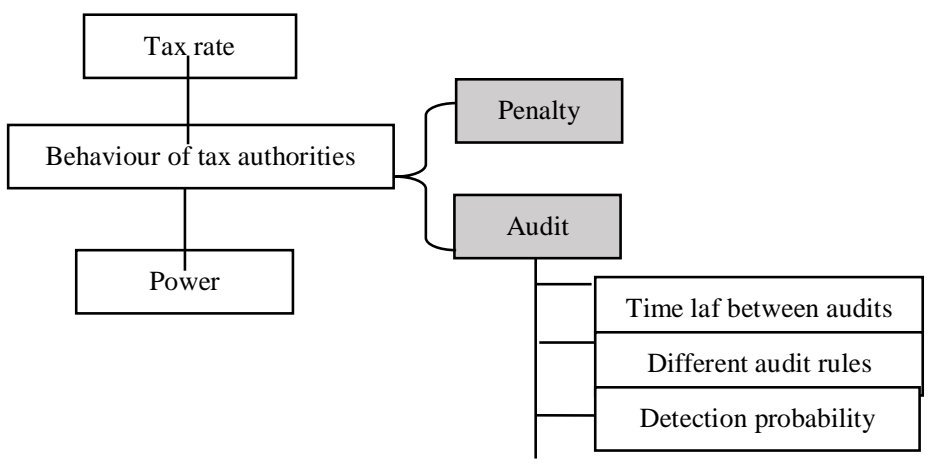

Taxpayer

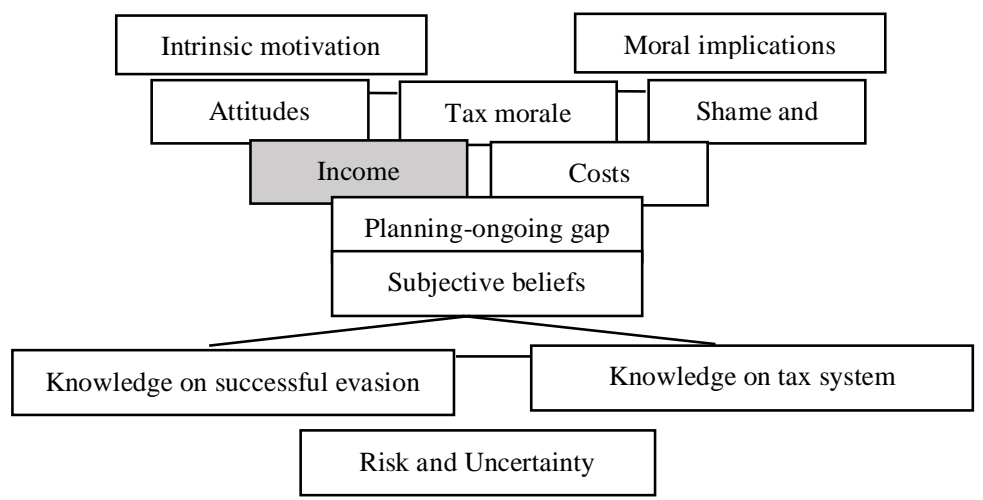

\section{Other taxpayers}

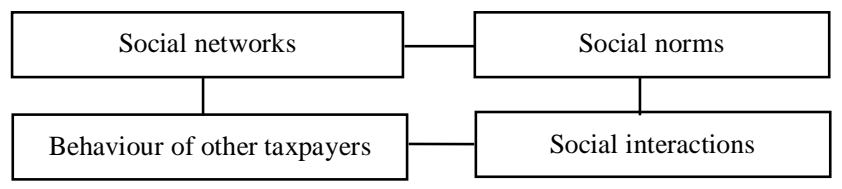

Source: Pukelienè and Kažemekaitytė, 2016:35.

\section{Literature}

Many international studies were performed to date to test the slippery slope framework. In these studies, surveys or experimental methods are generally used to measure the effects of the two main determinants of the slippery slope framework and in addition to this, there are a few studies that use econometric methods. However, in this study those that directly explain the 
variables (trust in the authority and the power of authority) of the slippery slope framework are used. In this part of the study, the studies that have been made so far will be inspected.

Wahl, Kastlunger and Kirchler (2010) tested the slippery slope framework with two experimental methods, one in the laboratory and the other online. The first experiment was conducted with 120 students and the second one used 127 self-employed people. As a result of the first experiment, it was found that the trust in the authority and the power of authority had a positive effect on tax payments, that the trust in the authorities increased voluntary tax compliance while decreasing enforced tax compliance and the power of authority worked in the reversed direction, i.e. decreased voluntary compliance and increased enforced compliance. In the second experiment, the elements from the first one were expanded to include strategic behavior. The result was that where trust and power were at lower levels, strategic behavior was involved more and it had less of an involvement in the case of higher trust and power.

Muehlbacher, Kirchler and Schwarzenberger (2011) made a study on testing the trust and power variables of the slippery slope framework. They collected a large data set from Austria, United Kingdom and Czech Republic by a market research institute via online questionnaires and they selected these countries because of their difference of various aspects regarding taxation and other economic issues. At the end of the study, they find out that whereas voluntary compliance seems to be positively related to age and education, enforced compliance is negatively related to education.

Benk and Budak (2012) tested the slippery slope framework for Turkey through questionnaires administered to 300 self-employed people. They used the linear regression method in data analysis. The results support the basic arguments of the slippery slope framework that the power of the authorities drives enforced tax compliance and the trust in the authorities brings higher voluntary tax compliance.

Lemoine and Roland-Levy (2013) conducted a questionnaire on 320 students of economics in France to test the premises of the hypothesis of slippery slope. Four scenarios (high trust/high power, high trust/low power, low trust/high power and low trust/low power) were created in the study and the participants were randomly assigned to four survey groups. The findings of this test support the slippery slope framework and show that the stronger the perceptions of trust in the authorities and the power of authority, the higher is the tax compliance. Moreover, the study emphasized the importance of education in increasing voluntary tax compliance. 
Kogler et al. (2013) tested the basic assumptions of the slippery slope framework over the different scenarios with the variables of trust and power in four countries: Austria, Hungary, Romania and Russia. The findings support the assumptions of the hypothesis: in circumstances of high trust and strong power, the highest level of tax compliance and the lowest level of tax evasion were observed, with more power bringing enforced compliance and more trust voluntary compliance, and that the power of authorities and trust in the authorities were important determinants of tax compliance.

Kastlunger et al. (2013) wanted to test the slippery slope framework in Italy with 389 selfemployed taxpayers using a model of structural equality. It was found that while trust in the authority was positively correlated to voluntary tax compliance, the power of the authority was correlated to enforced compliance, which in turn encouraged tax evasion.

Hofmann et al. (2014) conducted two experimental studies with convenience samples of 261 taxpayers overall. The studies describe tax authorities as having low or high coercive power and/or low or high legitimate power. At the end of the study it was founded that coercive power did not reduce implicit trust in tax authorities; however, it had an effect on reason-based trust, interaction climate and intended tax compliance if applied solely.

Kogler, Muehlbacher and Kirchler (2015) performed a more comprehensive test on the variables of the slippery slope framework and included variables such as the perception of justice, deterrence (effectiveness of penalties) and social norms in their study. The survey was conducted with 476 self-employed taxpayers in Austria and the findings were in line with the premises of the slippery slope framework. Furthermore, the study found that the perceptions of procedural and distributive justice were related to voluntary compliance through the element of trust, whereas punitive justice and deterrence were related to voluntary compliance through trust and enforced compliance through power. Even though social norms showed a strong relationship with voluntary and enforced compliance, they were not related to power and trust. Pukeliene and Kazemekaityte (2016) studied the tax behavior in 28 European Union countries through the period 2003-2014. The analysis, made with the panel data analysis method, included a diverse set of variables such as tax ethics, trust in the authorities, power of authority, economic development level, collectivism, gender, long-term trends, tastes, and preferences. The analysis showed that tax ethics, socio-cultural variables, and the taxpayer-administration relation had a significant effect on tax attitudes and behaviors. Within the framework of the slippery slope framework, it was found that the power of the authorities was mainly related to 
a negative reaction to the measures of enforcement, trust had a positive effect on compliance, and the interaction between trust and power could improve non-compliance.

Hofmann et al. (2017) measured the effects of coercive and legitimate power on tax compliance with four experiments. In the experiments, the single and combined impact of coercive and legitimate power on these processes and on intended cooperation is investigated within two exemplary contexts (tax contributions, insurance claims). Findings reveal that coercive power increases an antagonistic climate and enforced compliance, whereas legitimate power increases reason-based trust, a service climate and voluntary cooperation. In addition, legitimate power is additionally having a negative effect on an antagonistic climate and a positive effect on enforced compliance; these findings lead to a modification of theoretical assumptions.

Mardhiah, Miranti and Tanton (2019) extended the premises of the slippery slope framework to include different variables (tax penalties, audit, behavioral factors, perception of justice, etc.) that affected the trust in and power of the authorities and analyzed tax compliance through these variables. The analysis included in the study was a result of face-to-face interviews with 500 taxpayers in Indonesia. The findings showed that all variables included in the study had a significant effect on trust and power, that trust in the authorities brought voluntary compliance and that voluntary compliance increased total tax compliance.

Silva, Guerreiro and Flores (2019) investigated both classical economic paradigm and service paradigm because of the unlimited role of the classical economic paradigm on tax compliance. In their study, they aimed to evaluate both paradigms and their influences on the tax collection level and seeks to determine whether they affect enforced and voluntary tax compliance. For this reason, they made surveys to 389 Brazilian respondents with an average of 34 years and the results confirm the existence of trust-based interactions between taxpayers and public administration that leads to voluntary compliance, while policies based on the imposition of power result in enforced compliance.

Batrancea et al. (2019) studied the determinants of tax compliance across 44 nations ${ }^{5}$ from five continents ${ }^{6}$. They used data a from an experimental scenario study and they found that trust in authorities and power of authorities, as defined in the slippery slope framework, increase tax

\footnotetext{
${ }^{5}$ Egypt, Ghana, Morocco, South Africa, Brazil, Canada, Colombia, Mexico, United States, Bhutan, China, Hong Kong, India, Indonesia, Iran, Israel, Japan, Pakistan, South Korea, Thailand, United Arab Emirates, Austria, Finland, France, Germany, Greece, Hungary, Iceland, Ireland, Italy, Lithuania, Malta, Norway, Poland, Portugal, Romania, Russia, Slovenia, Spain, Sweden, Switzerland, Turkey, United Kingdom, Australia.

${ }^{6}$ Africa, Americas, Asia, Europe, Oceania.
} 
compliance intentions and mitigate intended tax evasion across societies that differ in economic, sociodemographic, political, and cultural backgrounds; trust and power increase compliance through different channels: trusted authorities register the highest voluntary compliance, whereas powerful authorities register the highest enforced compliance. Finally the study indicates that despite some between-country variations, trust and power are identified as important determinants of tax compliance across all nations.

\section{Basic Explanations About the Analysis}

\subsection{Method and Aim}

Panel data analysis achieved an important status especially from the beginning of 2000s and the importance and value of this analysis gradually increased in the field of econometrics (Nerlove et al., 2008:13). As one of the most important reasons for using panel data analysis is the possibility to reveal the dynamic relationships between variables through such a data set, the method of panel data analysis is one of the most notable and popular areas of research today (Nerlove et al., 2008:21).

Many different data types are used in econometric studies, but the methods available for these data types differ in many aspects. In general, three types of data are used in analyses such as time series data, horizontal section data and panel data. Time series data show the changes that occur in variables over time units, such as day, month, season or year. Horizontal section data are the data collected from different units at a certain point in time, while panel data are characterized by the conglomeration of horizontal sectional observations on units such as individual, country, company or household in a certain period of time (Yerdelen Tatoğlu, 2016:1-2). In other words, panel data puts together a combination of time series and horizontal section data.

Panel data can obtain several advantages. As a general characteristic, pure time-series data contain no information about individual differences and pure cross-section data contain no information about period-specific differences; so it is not possible to explore effects of individual-specific variables from time-series data and to examine effects of time-specific variables from cross-section data (Biørn, 2016:3). Panel data do not have, or have to a far 
smaller degree, these limitations, not least because such data admit many useful transformations (Biørn, 2016:3).

The aim of this study is examining the relationship between the elements that affect structure of the society and tax compliance based on its theoretical framework. In this respect, this analysis will be applied by using the main determinants of the slippery slope framework. As the analysis will compound several factors which constitutes the structure of the society and these factors will be evaluated by making a classification and putting the factors into different groups of social and economic variables, panel data is chosen to search both the effects of time periods and variables because of the abundance.

The structural elements include various socio-economic elements on the basis of theories examining tax compliance and in line with the OECD assessments. The aim of the analysis is to investigate any effect that the social structure factors might have on tax compliance and to measure its direction and magnitude, taking the slippery slope framework as the starting point. Because each country has its own tax system reflecting its unique social, economic, and political characteristics and the tax structure is also subject to change due to changes in economic, social, and political structures. In conclusion, it is of great importance to take into account the characteristics of the social structure when formulating the tax system, because only then could citizens or institutions fulfill their duties and comply with the system in increasing degrees.

\subsection{Variables and Data Set}

The study covers the period 2007-2017, i.e. the dimension of time extends to nine years. As for the dimension of horizontal section, data from 121 countries were used. As the study had both horizontal section and time dimensions, the method of panel data analysis was chosen and the software Stata was used for analysis.

The dependent variable is $\operatorname{tax}_{i t}$, where tax is tax compliance, $t$ is time, and $i$ is the country, thus it shows the level of tax compliance in a country during a time period. The data set was developed using the PricewaterhouseCoopers $(\mathrm{PwC})$ and the "Paying Taxes" reports of the World Bank ${ }^{7}$. These reports state the importance of both the costs of taxes and the level of tax

\footnotetext{
${ }^{7}$ All reports beginning with the Paying Taxes 2010 through Paying Taxes 2018 were used to obtain data and the title of each report contains the data for the two previous periods. For example, Paying Taxes 2018 report includes data for 2016.
} 
compliance for businesses. Therefore, the index was measured as the "overall paying taxes rank" covering all the sub-variables of the total rate of taxes, time needed for tax compliance, and the number of tax payments (PwC and World Bank, 2013:8). In the measurements of this index, all taxes and social security premiums paid by medium-sized enterprises (at federal, central, or local level) are included (PwC and World Bank, 2015:100).

Reports show the tax compliance variable according to the country rankings included in the analysis that year. For example, if 180 countries were included in the analysis that year, a particular country's score is calculated according to its rank among 180 countries. In the analysis conducted as part of the study, this variable was taken into consideration as a percentage value for consistency with other variables.

The sub-variables showing the level of tax compliance, they are determined as follows ( $\mathrm{PwC}$ and World Bank, 2014:124-126):

- Total tax rate: when calculating the total tax rate, the costs of all taxes including the corporate tax, taxes paid by the employer on behalf of the employee and social security contributions (including pension funds), property and municipal taxes and motor vehicle taxes. However, withholding taxes, such as personal income tax, are not included. The total tax rate is calculated by dividing the total enterprise tax by profit.

- Time needed for tax compliance: the time concept for the variable is expressed in hours. This variable includes the corporate tax, VAT or sales tax, and taxes on wage earners in terms of the time needed to prepare and submit the statement and issue the tax payment (online or in tax administration).

- Number of tax payments: this variable contains information on the total number of taxes and social security premiums paid, payment method, frequency of payments and frequency of filing a declaration. Since most medium-sized enterprises prefer to submit an electronic statement, these are the statements taken into consideration in the calculations.

As for the independent variables to be used in the analysis, they are determined as follows:

$X_{1 i t}=$ gov $_{i t}$ (government effectiveness): effectiveness of the state in the country $\mathrm{i}$, during the period t. This variable is used in the analysis as one of the main variables of the slippery slope 
framework $^{8}$, namely, the trust in the authority. The Index is among the Worldwide Governance Indicators and is derived from World Bank data.

Effectiveness of the state is the quality of public and civil services and their degree of independence from political pressure, government's efficiency in formulating and implementing policies and its credibility as far as the commitment to these policies is concerned. In the formulation of this index, the following are taken into consideration: the perceptions regarding the quality of bureaucracy, transportation (including public transport), health, education, infrastructure (including any damage that might occur due to terrorist attacks, strikes, or natural disasters), repair and maintenance, waste disposal, electricity, and drinking water, as well as the state's success in managing itself during natural disasters, legislative regulations, public services, and economic crises. As we go from 0 to 100, The effectiveness of the state is expressed on a scale of 0 to 100, with 0 being the least effective and 100 the most effective and as the citizens' trust will also increase on a parallel scale, tax compliance is expected to follow the same course in the same direction by increasing voluntary tax compliance.

$X_{2 i t}=a u_{i t}$ (strength of auditing and reporting standards): demonstrates the strength of audit and reporting standards, with data based on the Global Competitiveness Report prepared by the World Economic Forum. The index measures the effectiveness of audits, as well as the applicability of accounting standards. The index values are shown on a scale of 1 to 7 in the reports, 1 being the lowest and 7 the highest in terms of the power of audit and reporting standards. This scale is the product of a study with 13.877 surveys conducted in 135 countries. In this study, this variable was taken as a range with the maximum value of 7 and was converted to the maximum value of 100 to secure its compatibility with other variables.

$X_{3 i t}=\operatorname{reg}_{i t}$ (regulation): shows the rank of regulation (which is a variable of economic freedom) and is created using Fraser Institute data. Regulation index measures how regulations restrict entry into markets and interfere with the freedom to engage in voluntary exchange reduce economic freedom and the variables which constitute regulation index focus on regulatory restraints that limit the freedom of exchange in credit, labor, and product markets (Gwartney et $a l, 2018: 5)$. This index consist of three main variables such as credit market regulations (ownership of banks, private-sector credit, interest rate controls/negative real interest rates),

\footnotetext{
${ }^{8}$ For detailed information, see Pukeliene and Kazemekaityte, 2016:39.
} 
labor market regulations (hiring regulations and minimum wage, hiring and firing regulations, centralized collective bargaining, hours regulations, mandated cost of worker dismissal, conscription) and business regulations (administrative requirements, bureaucracy costs, starting a business, extra payments/bribes/favoritism, licensing restrictions) (Vasquez and Porcnik, 2018:17). The variable comprised a range of $0-10$, but was converted to one with the maximum value of 100 in order to secure its compatibility with other variables.

$X_{4 i t}=\operatorname{sm}_{i t}$ (sound money): The variable of access to sound money is determined by the Fraser Institute and contains sub-variables such as the size of the currency, standard deviation of inflation, inflation rate in the most recent year, or the freedom of opening bank accounts in foreign currency. This index focuses on the importance of money and relative price stability in the exchange process and sound money -money with relatively stable purchasing power across time- reduces transaction costs and facilitates exchange, thereby promoting economic freedom; in this while the four components of this area provide a measure of the extent to which people in different countries have access to sound money (Gwartney et al, 2018:5). The variables were on a range between 0 and 10, but were converted to a range with the maximum value of 100 for compatibility with the other variables.

$X_{5 i t}=$ lawit (rule of law): the rule of law is among the variables defined by the World Governance Indicators and it is expected that the increase in the variable will increase tax compliance, as well. As a matter of fact, this variable is included in the analysis to represent the variable of power of authority, which is one of the main variables in the slippery slope framework ${ }^{9}$. The sub-variables accounted for in the formulation of this variable include the fairness and speed of the judicial process, civil justice, criminal justice, protection of intellectual property rights, judicial independence, trust in the judiciary and law enforcement systems, and trust in the legislative process.

$X_{6 i t}=e d u_{i t}(e d u c a t i o n$ index $)$ : the education index shows the level of education in the country $\mathrm{i}$ during the $t$ period and is taken from the Legatum Institute data. The index was prepared with consideration of the following: access to education (wide range and accessibility of educational services, adult and young literacy rate, girls' schooling rate as compared to that of boys, Gini coefficient in the distribution of educational services), quality of education (citizen perceptions of the learning level of children, quality of primary and secondary education, rate of completion

\footnotetext{
${ }^{9}$ For detailed information, see Pukeliene and Kazemekaityte, 2016:39.
} 
of primary education, degree of satisfaction with local schools, number of the best universities, international reputation of the universities) and the human capital of the workforce (skills in the workforce promoting research and development, years in secondary school per worker, higher education level per worker, the percentage of students in the secondary education age group and enrolled in technical/vocational schools) (Legatum Institute, 2017:54). The education index is on a range of 0 to 100 , with 0 representing the lowest and 100 the highest level of education in the country. As the increase in education level improves the tax ethics and awareness of citizens, tax compliance is expected to increase in parallel with it.

$X_{7 i t}=\sec _{i t}$ (security and safety): in order to invest in a country, ensure sustainable development, and increase welfare, that country and its citizens must have safe living conditions (Legatum Institute, 2017:53). The security index was included in the analysis because of its importance in this regard and its data were selected from the Legatum Prosperity Index. The following were factored in when creating this index: national security (how to protect nationals from conflict and violence, also including coup, torture, disappearance in custody, and political imprisonment, as well as mortality in wars, casualty rate in civil and ethnic wars, scale of the political terror by the state, refugees by country of origin, and terrorist death rate), personal security (the degree of safety of individuals and property in daily life, rate of murder and theft, and night-time street safety), and secure living standards (adequate food and accommodation, the safety of the environment and infrastructure) (Legatum Institute, 2017:53). The security index is on a range of 0 to 100, with 0 being the lowest and 100 the highest and it is expected to increase in parallel with tax compliance.

\section{The Analysis on the Relationship Between Fiscal Sociology and the Slippery Slope Framework}

\subsection{Models}

In creating the model for defined variables, during the measurement of the relation between tax compliance and social and economic variables, it was ensured that the variables were minimally related to each other. The interactions among variables were measured to minimize the potential for the issue of multiple linear connections and they were found to be very weak, weak, or medium in intensity. The variables of the trust in authority and the rule of law had strong 
correlations among one another. Furthermore, the variable of the rule of law indicated social and the variable of the effectiveness of the state indicated economic variables. Therefore, these variables were examined in different models in order to secure more effective results for the analysis. The relationship between tax compliance and the eight independent variables used in the analysis were examined within the framework of two separate models, as economic and social variables respectively, as follows:

$$
\begin{array}{ll}
\text { First model } & \operatorname{tax}_{i t}=\beta_{0}+\beta_{1} \text { govit }_{i t}+\beta_{2} a u_{t}+\beta_{3} \operatorname{reg}_{i t}+\beta_{4 \mathrm{Sm}_{i t}}+u_{i t} \\
\text { Second model } & \operatorname{tax}_{i t}=\beta_{0}+\beta_{1} \operatorname{law}_{i t}+\beta_{2} e d u_{i t}+\beta_{3} \sec _{i t}+u_{i t}
\end{array}
$$

\subsection{Countries Included in the Analysis}

The data from 121 countries included in the analysis to measure the effects of variables on tax compliance within the framework of the models created are analyzed through a classification of these countries for more effective results. During this classification, as it is assumed that especially the variables of trust in and power of authorities varied according to the level of development of the countries, the analysis is based on the classification made by World Bank on the basis of the degrees of income levels of these countries. Accordingly, countries were classified as low income countries, lower middle income countries, upper middle income countries and high income countries as shown in Table 1.

\begin{tabular}{|c|c|c|c|}
\hline $\begin{array}{l}\text { Low income } \\
\text { countries (14) }\end{array}$ & $\begin{array}{l}\text { Lower middle } \\
\text { income countries } \\
(27)\end{array}$ & $\begin{array}{l}\text { Upper middle } \\
\text { income countries } \\
(37)\end{array}$ & $\begin{array}{l}\text { High income } \\
\text { countries (43) }\end{array}$ \\
\hline Benin & Bangladesh & Albania & Australia \\
\hline Burkina Faso & Bolivia & Algeria & Austria \\
\hline Burundi & Cambodia & Argentina & Belgium \\
\hline Chad & Cameroon & Armenia & Canada \\
\hline Ethiopia & Egypt & Azerbaijan & Chile \\
\hline Madagascar & El Salvador & Botswana & Croatia \\
\hline Malawi & Ghana & Brazil & Cyprus \\
\hline
\end{tabular}

Table 1. Countries in the Analysis by World Bank Classification on Level of Income 
FSECON DAYIOĞLU ERUL, R. (2020), "Testing the Slippery Slope Framework in the Scope of Fiscal Sociology: A Study on the Classification of Income Levels", Fiscaoeconomia, Vol.4(1), 61-93.

\begin{tabular}{|c|c|c|c|}
\hline Mali & Honduras & Bulgaria & Czech Republic \\
\hline Mozambique & India & China & Denmark \\
\hline Nepal & Indonesia & Colombia & Estonia \\
\hline Rwanda & Kenya & Costa Rica & Finland \\
\hline Tajikistan & Kyrgyz Republic & Dominican Republic & France \\
\hline Tanzania & Lesotho & Ecuador & Germany \\
\hline \multirow[t]{26}{*}{ Uganda } & Mauritania & Georgia & Greece \\
\hline & Moldova & Guatemala & Hong Kong \\
\hline & Mongolia & Guyana & Hungary \\
\hline & Morocco & Iran & Iceland \\
\hline & Nicaragua & Jamaika & Ireland \\
\hline & Nigeria & Jordan & Italy \\
\hline & Pakistan & Kazakhstan & Japan \\
\hline & Philippines & Lebanon & Latvia \\
\hline & Senegal & Macedonia & Lithuania \\
\hline & Tunisia & Malaysia & Luxembourg \\
\hline & Ukraine & Mauritius & Malta \\
\hline & Vietnam & Mexico & Netherlands \\
\hline & Zambia & Montenegro & New Zealand \\
\hline & Zimbabwe & Namibia & Norway \\
\hline & & Paraguay & Oman \\
\hline & & Peru & Panama \\
\hline & & Romania & Poland \\
\hline & & Russia & Portugal \\
\hline & & Serbia & Qatar \\
\hline & & Sri Lanka & Saudi Arabia \\
\hline & & South Africa & Singapore \\
\hline & & Thailand & Slovak Republic \\
\hline & & Turkey & Slovenia \\
\hline & & Venezuela & Spain \\
\hline & & & Sweden \\
\hline & & & Switzerland \\
\hline
\end{tabular}




\begin{tabular}{|l|l|l|} 
& & Trinidad ve Tobago \\
United Kingdom \\
United States \\
Uruguay
\end{tabular}

Source: The World Bank, https://datahelpdesk.worldbank.org/knowledgebase/articles/906519world-bank-country-and-lending-groups, 11.11.2019.

According to the classification made by World Bank; low income countries are defined as those with a GNI per capita of $\$ 1.025$ or less in 2018 , lower middle income economies are those with a GNI per capita between $\$ 1.026$ and $\$ 3.995$; upper middle income economies are those with a GNI per capita between $\$ 3.996$ and $\$ 12.375$; high income economies are those with a GNI per capita of $\$ 12.376$ or more. Furthermore, although there are 31 low income, 47 low middle income, 60 upper middle income and 80 high income countries in the classification, 14 low income, 27 low middle income, 37 upper middle income and 43 high income countries are included in the analysis due to lack of the data.

\subsection{Choosing the Right Model}

To select the right model for the analysis, some tests were applied for all country groups and on two models to test the effects of unit and time factors. In this context the following were used:

- $f$ test to choose between the classical model and the fixed effects model (testing the hypothesis $\mathrm{H}_{0}$ where all unit or time effects equal zero),

- Hausman test $\left(\mathrm{H}_{0}\right.$ hypothesis was based on the assumption that the random effects model was appropriate) to choose between the fixed effects model and the random effects model, and

- the test of Likelihood Ratio (LR) test $\left(\mathrm{H}_{0}\right.$ hypothesis was based on the assumption that the classical model was correct).

Effects of unit and time were also tested with these. Models selected to be applied as a result of these tests are shown below.

Table 2. Model Types Applied in the Analysis 


\begin{tabular}{|l|l|l|l|l|}
\hline & $\begin{array}{l}\text { Low income } \\
\text { countries }\end{array}$ & $\begin{array}{l}\text { Lower middle } \\
\text { income countries }\end{array}$ & $\begin{array}{l}\text { Upper middle } \\
\text { income } \\
\text { countries }\end{array}$ & $\begin{array}{l}\text { High income } \\
\text { countries }\end{array}$ \\
\hline First model & Random effects & Random effects & $\begin{array}{l}\text { Random } \\
\text { effects }\end{array}$ & Fixed effects \\
\hline Second model & Fixed effects & Fixed effects & Fixed effects & Fixed effects \\
\hline
\end{tabular}

According to the results obtained from the tests, none of the models showed the effect of time upon testing the existence of the time dimension, which led to the conclusion that one-way models should be applied for both models in all country groups. As a result, one-way fixed effects model or one-way random effects model was used in all models. For the fixed effects model, the intergroup estimation method was used for analysis and the likelihood method was used for the random effects model.

The structure of all three models used in panel data analysis (classical model, fixed effects model and random effects model) were based on the assumption that there were no problems of varying variance (heteroscedasticity), auto-correlation, or inter-unit correlation (horizontal cross-sectional dependence) (Güriş, 2015:71). Therefore, models required further testing to determine whether these three problems were present.

If at least one of the problems of variance, autocorrelation, or inter-unit correlation is present in the models, then either standard errors should be corrected without any intervention on the parameter estimates (resistant standard errors should be obtained) or estimates should be made with appropriate methods (Yerdelen Tatoğlu, 2016:251-252). The mentioned tests ${ }^{10}$ were performed and it was concluded that the final results should be obtained by applying resistant estimators according to the test results ${ }^{11}$.

\section{The Results of the Analysis}

Various methods are proposed for resistant estimators in the field literature, however, the Beck-Katz (1995) estimator was used in this study as one of the most widely used

\footnotetext{
${ }^{10}$ In order to test the variance, the modified Wald test was tested with the constant effects model; the Levene, Brown, and Forsythe tests were used in the random effects model; both in the constant and random effect models the autocorrelation was tested using the Bhargava, Franzini, and Narendranathan's Durbin Watson and BaltagiWu's Local Best Invariant Tests; and the Pesaran test was used in both models to test the interdivisional correlation.

${ }^{11}$ For the test results, see the "Appendix A and Appendix B".
} 
estimators. The results of the first model obtained with the Beck-Katz method are shown in Table 3.

First model results show that the explanatory power of the model varies between 33 per cent and 88 per cent in terms of country groups, which in turn is an indication that the variables' explanatory power is good, especially for high income countries. It is thought that this result depends on the fact that these countries are the most developed countries and the economic variables included in the analysis best reflect these countries.

First of all, the model findings show that government effectiveness, which is one of the main variables of the slippery slope framework and symbolizes trust in authorities, is statistically significant and positive for all country groups. This finding supports the argument of the slippery slope framework that "trust in authorities increases tax compliance in general, by increasing voluntary tax compliance in particular." This index shows the citizen satisfaction with the services provided by the government, the quality of public services, the extent of applicability of the regulations made by the state, in short the state's success in making policies and having them accepted by citizens. In other words, it reflects the citizen trust in the authorities/state and its policies, therefore, any increase in this index means more positive citizen perception about government policies, further internalization of the authority, and higher voluntary tax compliance. After all, positive relations and cooperation between taxpayers and tax administration further voluntary tax compliance. 
Table 3. First Model Results Considering Heteroscedasticity, Autocorrelation, Interdivisional Correlation

\begin{tabular}{|c|c|c|c|c|}
\hline $\begin{array}{l}\text { Variable } \\
\text { tax }\end{array}$ & $\begin{array}{l}\text { Low income } \\
\text { countries }\end{array}$ & $\begin{array}{l}\text { Lower middle } \\
\text { income } \\
\text { countries }\end{array}$ & $\begin{array}{l}\text { Upper middle } \\
\text { income } \\
\text { countries }\end{array}$ & $\begin{array}{l}\text { High income } \\
\text { countries }\end{array}$ \\
\hline gov & $\begin{array}{l}0.7042 * * * \\
(0.000)\end{array}$ & $\begin{array}{l}0.2053 * \\
(0.063)\end{array}$ & $\begin{array}{l}0.1450 * \\
(0.065)\end{array}$ & $\begin{array}{l}0.3778^{* * *} \\
(0.000)\end{array}$ \\
\hline au & $\begin{array}{l}0.4301 * \\
(0.060)\end{array}$ & $\begin{array}{l}0.0786 \\
(0.494)\end{array}$ & $\begin{array}{l}0.7332 * * * \\
(0.000)\end{array}$ & $\begin{array}{l}0.3572 * * \\
(0.008)\end{array}$ \\
\hline reg & $\begin{array}{l}-0.0946 \\
(0.650)\end{array}$ & $\begin{array}{l}0.2034 \\
(0.220)\end{array}$ & $\begin{array}{l}0.1953 * * \\
(0.039)\end{array}$ & $\begin{array}{l}0.3348 * * * \\
(0.006)\end{array}$ \\
\hline $\mathbf{s m}$ & $\begin{array}{l}-0.0547 \\
(0.657)\end{array}$ & $\begin{array}{l}0.0104 \\
(0.912)\end{array}$ & $\begin{array}{l}0.4120^{* * *} \\
(0.000)\end{array}$ & $\begin{array}{l}-0.4178 * * \\
(0.005)\end{array}$ \\
\hline Fixed & $\begin{array}{l}3.8660 \\
(0.799)\end{array}$ & $\begin{array}{l}12.0505 \\
(0.243)\end{array}$ & $\begin{array}{l}-49.028 * * * \\
(0.000)\end{array}$ & $\begin{array}{l}25.4420^{* *} \\
(0.021)\end{array}$ \\
\hline $\mathbf{R}^{2}$ & 0.6303 & 0.3353 & 0.4560 & 0.8849 \\
\hline
\end{tabular}

Note: $* * *, * *$ and $*$ indicate that the null hypothesis is rejected in $1 \%, 5 \%$ and $10 \%$, respectively.

Although this index has positive effects on tax compliance for all country groups, the highest effect occurs on low income countries. This result is the expected, because trust in authorities takes the lowest values in these countries, that's why if the level of citizens' trust increases, it brings the highest positive effect on tax compliance in comparison to other country groups. As shown in the table, regarding strength of auditing and reporting standards, one unit increase in the level of audit has a positive effect in the same direction on tax compliance for all country groups and the variable is statistically significant for all country groups except for lower middle income countries. This positive effect is in line with the prediction of the expected benefit model that the increase in audit rates reduces the amount of tax evasion and the results obtained are in accordance with the theory, in spite of some existing literature to the effect that audits have negative or zero effect on tax compliance. The fact that the least important positive effect of a one-unit increase in the variable is seen in high income countries is thought to be due to the high level of audits, having strong audits or more developed tax systems in these countries. 
Regulation variable is statistically significant for only upper middle income and high income countries. As this variable is one of the sub-variables of economic freedom, it is expected that the values are only statistically significant for these country groups which have the highest levels of economic freedom. Regulation index indicates the easiness of starting a new project or entering a new market because of the regulations made by governments, therefore, these findings depend on the fact that these two country groups have the most developed economies in comparison to others and governments of these countries have more authority to regulate. In addition to this, the effects are positive as expected because the easier entering a new market, the higher the level of tax compliance is.

The variable of access to sound money is also statistically significant for only upper middle income and high income countries and has a negative effect on tax compliance in high income countries. This is thought to be due to the increase in tax planning techniques. As a matter of fact, the increasingly easy access to tax havens and shifting investments are a negative influence on tax compliance. High inflation rate, which creates a Tanzi effect and decreases tax compliance is yet another factor in the results obtained.

With a general point of the view, it can be seen that all the variables are statistically significant for upper middle income and high income countries. As they are the most developed countries with regard to social and economic background, the explanatory power of the model has the highest values for these countries.

The final results of the second model obtained using a resistant estimator are given in Table 4 and the model's accounting levels for variables vary between 40 per cent and 61 per cent which can be evaluated to be enough to explain the model.

The first remarkable point about the model findings is that the results of the rule of law variable confirm the basic assumption of the slippery slope framework. Since this variable represents the power of authority, the premise of the slippery slope framework that the power of authority variable accounts for the enforced tax compliance is found to be in accordance with the hypothesis for all country groups. This variable is statistically significant for all country groups and to have a positive effect on tax compliance. 
Table 4. Second Model Results Considering Heteroscedasticity, Autocorrelation, Interdivisional Correlation

\begin{tabular}{|c|c|c|c|c|}
\hline $\begin{array}{l}\text { Variable } \\
\text { tax }\end{array}$ & $\begin{array}{l}\text { Low income } \\
\text { countries }\end{array}$ & $\begin{array}{l}\text { Lower middle } \\
\text { income } \\
\text { countries }\end{array}$ & $\begin{array}{l}\text { Upper middle } \\
\text { income } \\
\text { countries }\end{array}$ & $\begin{array}{l}\text { High } \\
\text { income } \\
\text { countries }\end{array}$ \\
\hline law & $\begin{array}{l}0.7504 * * * \\
(0.000)\end{array}$ & $\begin{array}{l}0.4919 * * * \\
(0.000)\end{array}$ & $\begin{array}{l}0.3938 * * * \\
(0.000)\end{array}$ & $\begin{array}{l}0.7434 * * * \\
(0.000)\end{array}$ \\
\hline edu & $\begin{array}{l}0.4225 * * * \\
(0.000)\end{array}$ & $\begin{array}{l}0.0281 \\
(0.897)\end{array}$ & $\begin{array}{l}0.9354 * * * \\
(0.003)\end{array}$ & $\begin{array}{l}0.0169 \\
(0.950)\end{array}$ \\
\hline sec & $\begin{array}{l}0.1323^{*} \\
(0.066)\end{array}$ & $\begin{array}{l}0.2057 * \\
(0.077)\end{array}$ & $\begin{array}{l}-0.3076^{*} \\
(0.073)\end{array}$ & $\begin{array}{l}-0.3316 \\
(0.100)\end{array}$ \\
\hline Fixed & $\begin{array}{l}-12.7783 \\
(0.039)\end{array}$ & $\begin{array}{l}-0.1513 \\
(0.991)\end{array}$ & $\begin{array}{l}-5.9093 \\
(0.761)\end{array}$ & $\begin{array}{l}40.7462 * * \\
(0.024)\end{array}$ \\
\hline $\mathbf{R}^{2}$ & 0.4048 & 0.4748 & 0.4332 & 0.6135 \\
\hline
\end{tabular}

Note: $* * *, * *$ and $*$ indicate that the null hypothesis is rejected in $1 \%, 5 \%$ and $10 \%$, respectively.

Furthermore, the positive effect of the variable on tax compliance is highest in low income countries. As the countries in this group are underdeveloped both in their governance and democracy and in economic and social terms, this situation is ascribed to their generally inadequate and ineffective legal systems. As a matter of fact, the high power of the authorities leads to enforced compliance because of the strict and coercive administrative practices, which in turn results with an increase in the power of administration in less developed countries which are not free in management and developed in socio economic ways, thus enforced compliance increases to high levels.

The effect of the education index on tax compliance is statistically significant for low income and upper middle income countries. Although it is not statistically significant for other country groups, the effect of the variable on tax compliance is positive for all, as expected. Not being statistically significant for high income countries can be evaluates with regard to their social and cultural development level. This means that as they have the highest development level of those, making a policy of increasing tax compliance by carrying the education level to the upper levels has no effects. In other words, in the framework of fiscal sociology, increasing education level is not a good policy or choice for these countries to increase compliance. 
As for the results of the security variable, it is seen that the variable is statistically significant for all groups except for high income countries. The fact that it is not found statistically significant for these countries might indicate a higher level of trust in authority and hence, this variable does not have an effect of increasing tax compliance in the fiscal sociology. Findings with regard to the security variable are especially important for less developed countries and the coefficient of the variable is positive for these groups as expected. This shows that tax compliance of the citizens in these countries, who do not have a very high level of security, may increase significantly if the security feeling increases.

A general review of the results of the analysis indicate that the main variables of the slippery slope framework, namely trust in the authority and power of the authority have a significant effect for improving tax compliance as compared to other variables. A classification according to the levels of income also supports the view that these variables should bear more weight in policy making than other variables. This result shows that in defining taxation policies the factors of trust and power should enjoy special consideration; however, as a normal outcome of the differentiation of income levels, these factors should be taken into consideration if a variable at a higher level is present.

\section{Conclusion}

The most important priority of fiscal sociology is to promote the interaction between social structure and fiscal policies. This issue depends on the fact that tax systems reflect the same characteristics as the social structure, in other words, a taxation system using the same fundamentals as the society itself will be met with less resistance and be more successful.

Considering the fact that one of the variables showing the success level of the tax system is tax compliance, the relationship between the tax system and the components of the social structure and the main hypothesis of the slippery slope framework are analyzed in this study. After the variables affecting tax compliance are determined depending on tax models/theories, these variables are classified into two categories that are economic and social models to take effective results.

As the main argument of the slippery slope framework that "trust in the authority and the power of authority explain tax compliance", the study focuses on analyzing the effects of these two variables in order to test the slippery slope framework and some other social and economic variables. As it is assumed that especially the variables of trust in and power of authorities 
varied according to the level of development in the country, the analysis is based on the classification made by the World Bank on the basis of the degrees of income of these countries. As a result of the analysis made, main premises of the slippery slope framework are supported for all country groups. In other words, it is concluded that the variables of trust in and power of the authorities affect tax compliance positively. However, the results differs, as expected, at the level of income, in other words, development degrees. These results emphasize the view that the internal dynamics, social and economic order, and governance structure of a country must be given high priority and consideration in formulating tax policies and regulations in accordance with fiscal sociology.

\section{References}

Allingham, M. G. and Sandmo, A. (1972), "Income Tax Evasion: A Theoretical Analysis". Journal of Public Economics, 1, 323-338.

Batırel, Ö. F. (1996), “Tax Evasion and Voluntary Compliance”. Tax World Journal, 175, 5255.

Batrancea, L., Nichita, A., Olsen, J., Kogler, C., Kirchler, E., Hoelz, E., Weiss, A., Torgler, B., Fooken, J., Fuller, J., Schaffner, M., Banuri, S., Hassanein, M., Alarcón-García, G. , Aldemir, C., Apostol, O., Weinberg, D. B., Batrancea, I., Belianin, A., Gómez, F. J. B., Briguglio, M., Dermol, V., Doyle, E., Gcabo, R., Gong, B., Ennya, S., Essel-Anderson, A., Frecknall-Hughes, J., Hasanain, A., Hizen, Y., Huber, O., Kaplanoglou, G., Kudła, J., Lemoine, J. E., Leurcharusmee, S., Matthiasson, T., Mehta, S., Min, S., Naufal, G., Niskanen, M., Nordblom, K., Öztürk, E. B., Pacheco, L., Pántyaa, J., Rapanos, V., Roland-Lévy, C., Roux-Cesar, A. M., Salamzadeh, A., Savadori, L., Schei, V., Sharma, M., Summers, B., Suriya, K., Tran, Q., Villegas-Palacio, C., Visser, M., Xia, C., Yi, S. and Zukauskas, S. (2019), "Trust and power as determinants of tax compliance across 44 nations". Journal of Economic Psychology, 74, 1-15.

Benk, S. and Budak, T. (February 2012), "Power and Trust as Determinants of Voluntary Versus Enforced Tax Compliance: Empirical Evidence for The Slippery Slope Framework from Turkey”. African Journal of Business Management, 6(4), 1499-1505.

Biørn, E. (December 2016), Econometrics of Panel Data: Methods and Applications. Oxford Scholarship Online. 
Brun, B. L. (2013), "Fiscal Sociology: An Innovative Approach of Citizenship and Democracy Design”. In J. G. Backhaus (Edt.), Essentials of Fiscal Sociology: Conception of an Encyclopedia (pp. 11-14). Frankfurt.

Campbell, J. L. (1993), “The State and Fiscal Sociology”. Annual Review of Sociology, 19, 163 185.

Güriş, S. (2015), Panel Data Models with Stata. Istanbul: Der Bookstore.

Gwartney, J., Lawson, R., Hall, J. and Murphy, R. (2018). Economic Freedom of the World: 2018 Annual Report. Fraser Institute. Available from: https://www.fraserinstitute.org/studies/economic-freedom [Accessed 15.11.2019].

Hofmann, E., Gangl, K., Kirchler, E. and Stark, J. (2014), "Enhancing Tax Compliance through Coercive and Legitimate Power of Tax Authorities by Concurrently Diminishing or Facilitating Trust in Tax Authorities". Law and Policy, 36(3), 290-313.

Hofmann, E., Hartl, B., Gangl, K., Hartner-Tiefenthaler, M. and Kirchler, E. (January 2017), “Authorities' Coercive and Legitimate Power: The Impact on Cognitions Underlying Cooperation". Frontiers in Psychology, 8(5), 1-15.

James, S. and Alley, C. (2004), “Tax Compliance, Self-Assessment and Tax Administration”. Journal of Finance and Management in Public Services, 2(2), 27-42.

Juan, A., Lasheras, M. A., and Mayo, R. (1994), "Voluntary tax compliant behavior of Spanish income tax payers". Public Finance, 49, 90-105.

Kahneman, D. andTversky, A. (March 1979), "Prospect Theory: An Analysis of Decision under Risk”. Econometrica, 47(2), 263-292.

Kastlunger, B., Lozza, E., Kirchler, E. and Schabmann, A. (2013), "Powerful authorities and trusting citizens: The Slippery Slope Framework and tax compliance in Italy”. Journal of Economic Psychology, 34, 36-45.

Kirchler, E., Hoelzl, E. and Wahl, I. (2008), "Enforced Versus Voluntary Tax Compliance: The “Slippery Slope”' Framework”. Journal of Economic Psychology, 29, 210-225.

Kogler, C., Batrancea, L., Nichita, A., Pantya, J. and Belianin, A. (2013), “Trust and Power as Determinants of Tax Compliance: Testing the Assumptions of the Slippery Slope Framework in Austria, Hungary, Romania and Russia". Journal of Economic Psychology, 34, 169-180.

Kogler, C., Muehlbacher, S. and Kirchler, E. (February 2015), “Testing The 'Slippery Slope Framework’ Among Self-Employed Taxpayers”. Economics of Governance, 125-142. 
Legatum Institute (November 2017), The Legatum Prosperity Index 2017 (Eleventh Edition). Lemoine, J. E. and Roland-Levy, C. (May 2013), “Are Taxpayers, Who Pay Their Taxes, All Cooperative Citizens?”. Citizenship TeachingandLearning, 8(2), 195-213.

Mardhiah, M., Miranti, R. and Tanton, R. (February 2019), “The Slippery Slope Framework: Extending the Analysis by Investigating Factors Affecting Trust and Power". CESifo Working Papers, 7494.

Martin, I. W., Mehrotra, A. K. and Prasad, M. (2009), "The Thunder of History: The Origins and Development of The New Fiscal Sociology". In I. W. Martin, A. K. Mehrotra and M. Prasad (Eds.), The New Fiscal Sociology-Taxation in Comparative and Historical Perspective (pp. 1-27). Cambridge: Cambridge University Press.

McLure, M. (2003), "Fiscal Sociology". Economics Program School of Economics and Commerce, The University of Western Australia, Discussion Paper, No. 03.16, 1-10.

Muehlbacher, S., Kirchler, E. and Schwarzenberger, H. (2011), "Voluntary versus enforced tax compliance: empirical evidence for the 'slippery slope' framework". European Journal of Law and Economics, 32, 89-97.

Nerlove, M., Sevestre, P. and Balestra, P. (2008), “Introduction”, L. Matyas and P. Sevestre (Ed.). The Econometrics of Panel Data: Fundamentals and Recent Developments in Theory and Practice (Third Edition). Verlag Berlin Heidelberg: Springer.

OECD (October 2004), Compliance Risk Management: Managing and Improving Tax Compliance. Guidance Note. Paris.

OECD (2014), Measures of Tax Compliance Outcomes: A Practical Guide. Paris: OECD Publishing.

Padgett, J. F. (July 1981), "Hierarchy and Ecological Control in Federal Budgetary Decision Making”. American Journal of Sociology, 87(1), 75-129.

PricewaterhouseCoopers (PwC) and The World Bank, 2009, Paying Taxes 2010.

PricewaterhouseCoopers (PwC) and The World Bank, 2010, Paying Taxes 2011.

PricewaterhouseCoopers (PwC) and The World Bank, 2011, Paying Taxes 2012.

PricewaterhouseCoopers (PwC) and The World Bank, 2012, Paying Taxes 2013.

PricewaterhouseCoopers (PwC) and The World Bank, 2013, Paying Taxes 2014.

PricewaterhouseCoopers (PwC) and The World Bank, 2014, Paying Taxes 2015.

PricewaterhouseCoopers (PwC) and The World Bank, 2015, Paying Taxes 2016.

PricewaterhouseCoopers (PwC) and The World Bank, 2016, Paying Taxes 2017. 
PricewaterhouseCoopers (PwC) and The World Bank, 2017, Paying Taxes 2018.

PricewaterhouseCoopers (PwC) and The World Bank, 2018, Paying Taxes 2019.

Pukeliene, V. and Kazemekaityte, A. (2016), “Tax Behaviour: Assessment of Tax Compliance in European Union Countries". Ekonomika, 95(2), 30-56.

Roth, J. A., Scholz, J. T. and Witte, A. D. (1989), Taxpayer Compliance: An Agenda for Research. Philadelphia: University of Pennsylvannia Press.

Saruç, N. T. (2015), Tax Compliance: Theory and Policy. Ankara: Seçkin Publishing.

Silva, F. P., Guerreiro, R. and Flores, E. (2019), "Voluntary versus enforced tax compliance: the slippery slope framework in the Brazilian context". International Review of Economics, 66, 147-180.

Song, Y. and Yarbrough, T. E. (September/October 1978), “Tax Ethics and Taxpayer Attitudes:

A Survey". Public Administration Review, 38(5), 442-452.

The World Bank, https://www.worldbank.org/.

Vasquez, I. and Porcnik, T. (2018), The Human Freedom Index 2018-A Global Measurement of Personal, Civil and Economic Freedom. Cato Institute, The Fraser Institute, and the Friedrich Naumann Foundation for Freedom. Available from: https://www.fraserinstitute.org/sites/default/files/human-freedom-index-2018.pdf [Accessed 15.11.2019].

Yerdelen Tatoğlu, F. (October 2016), Panel Data Econometrics (Extended 3rd Edition). Istanbul: Beta Printing.

Yitzhaki, S. (1974), “A Note on Income Tax Evasion: A Theoretical Analysis". Journal of Public Economics, 3, 201-202.

Wahl, I., Kastlunger, B. and Kirchler, E. (October 2010), “Trust in Authorities and Power to Enforce Tax Compliance: An Empirical Analysis of the "Slippery Slope Framework"”. Law and Policy, 32(4), 383-406. 
Appendix A. First Model Results of Heteroscedasticity, Autocorrelation, Interdivisional

\section{Correlation}

\begin{tabular}{|c|c|}
\hline \multicolumn{2}{|c|}{ Low income countries } \\
\hline Heteroscedasticity & $\begin{array}{lll}\text { W0 }=4.7719590 & \mathrm{df}(13,112) & \text { Pr }>F= \\
0.00000153 & & \\
W 50=2.6398176 & \mathrm{df}(13,112) & \text { Pr }>F= \\
0.00298877 & & \\
W 10=4.7719590 & \mathrm{df}(13,112) & \text { Pr }>F= \\
0.00000153 & & \end{array}$ \\
\hline Autocorrelation & $\begin{array}{l}\text { modified Bhargava et al. Durbin-Watson }= \\
.64312239 \\
\text { Baltagi-Wu LBI }=.97387197\end{array}$ \\
\hline $\begin{array}{l}\text { Interdivisional } \\
\text { correlation }\end{array}$ & $\begin{array}{l}\text { Pesaran's test of } \quad \text { cross } \quad \text { sectional } \\
\text { independence }=1.987, \quad \operatorname{Pr}=0.0469\end{array}$ \\
\hline \multicolumn{2}{|c|}{ Lower middle income countries } \\
\hline Heteroscedasticity & $\begin{array}{lll}\text { W0 }=4.7695254 & \mathrm{df}(26,216) & \mathrm{Pr}>\mathrm{F}= \\
0.00000000 & & \\
\text { W50 }=2.2009530 & \mathrm{df}(26,216) & \mathrm{Pr}>\mathrm{F}= \\
0.00117323 & & \\
\mathrm{~W} 10=4.7695254 & \mathrm{df}(26,216) & \mathrm{Pr}>\mathrm{F}= \\
0.00000000 & & \end{array}$ \\
\hline Autocorrelation & $\begin{array}{l}\text { modified Bhargava et al. Durbin-Watson }= \\
.68574492 \\
\text { Baltagi-Wu LBI }=1.0937866\end{array}$ \\
\hline $\begin{array}{l}\text { Interdivisional } \\
\text { correlation }\end{array}$ & $\begin{array}{l}\text { Pesaran's test of } \quad \text { cross } \quad \text { sectional } \\
\text { independence }=1.476, \quad \operatorname{Pr}=0.1399\end{array}$ \\
\hline \multicolumn{2}{|c|}{ Upper middle income countries } \\
\hline Heteroscedasticity & $\begin{array}{lll}\text { W0 }=8.6854611 & \mathrm{df}(36,296) & \mathrm{Pr}>\mathrm{F}= \\
0.00000000 & & \\
\text { W50 }=2.7041477 & \mathrm{df}(36,296) & \mathrm{Pr}>\mathrm{F}= \\
0.00000233 & & \end{array}$ \\
\hline
\end{tabular}




\begin{tabular}{|l|l|}
\hline & $\begin{array}{l}\mathrm{W} 10=8.6854611 \mathrm{df}(36,296) \mathrm{Pr}>\mathrm{F}= \\
0.00000000\end{array}$ \\
\hline Autocorrelation & $\begin{array}{l}.54784523 \\
\text { Baltagi-Wu LBI }=.92459517\end{array}$ \\
\hline $\begin{array}{l}\text { Interdivisional } \\
\text { correlation }\end{array}$ & $\begin{array}{l}\text { Pesaran's test of cross sectional } \\
\text { independence }=-0.918, \mathrm{Pr}=0.3586\end{array}$ \\
\hline High income countries & $\begin{array}{l}\text { chi2 }(43)=3.1 \mathrm{e}+05 \\
\text { Prob }>\text { chi2 }=0.0000\end{array}$ \\
\hline Heteroscedasticity & $\begin{array}{l}\text { modified Bhargava et al. Durbin-Watson }= \\
.68533925 \\
\text { Baltagi-Wu LBI }=1.1477454\end{array}$ \\
\hline Autocorrelation & $\begin{array}{l}\text { Pesaran's test of cross } \\
\text { independence }=6.446, \text { Pr }=0.0000\end{array}$ \\
\hline $\begin{array}{l}\text { Interdivisional } \\
\text { correlation }\end{array}$ &
\end{tabular}

Appendix B. Second Model Results of Heteroscedasticity, Autocorrelation, Interdivisional Correlation

\begin{tabular}{|l|l|}
\hline \multicolumn{2}{|l|}{ Low income countries } \\
\hline Heteroscedasticity & $\begin{array}{l}\text { chi2 }(14)=3400.10 \\
\text { Prob>chi2 }=0.0000\end{array}$ \\
\hline Autocorrelation & $\begin{array}{l}\text { modified Bhargava et al. Durbin-Watson }= \\
58682895 \\
\text { Baltagi-Wu LBI }=.82515534\end{array}$ \\
\hline Interdivisional & $\begin{array}{l}\text { Pesaran's test of cross sectional } \\
\text { independence }=-0.461, \text { Pr }=0.6450\end{array}$ \\
\hline Lorrelation & $\begin{array}{l}\text { chi2 }(27)=6965.49 \\
\text { Prob }>\text { chi2 }=0.0000\end{array}$ \\
\hline Heteroscedasticity & $\begin{array}{l}\text { modified Bhargava et al. Durbin-Watson }= \\
.66030024\end{array}$ \\
\hline Autocorrelation &
\end{tabular}




\begin{tabular}{|c|c|}
\hline & Baltagi-Wu LBI $=1.0490115$ \\
\hline $\begin{array}{l}\text { Interdivisional } \\
\text { correlation }\end{array}$ & $\begin{array}{l}\text { Pesaran's test of } \quad \text { cross } \text { sectional } \\
\text { independence }=3.847, \quad \operatorname{Pr}=0.0001\end{array}$ \\
\hline \multicolumn{2}{|c|}{ Upper middle income countries } \\
\hline Heteroscedasticity & $\begin{array}{l}\text { chi2 }(37)=6557.33 \\
\text { Prob }>\text { chi } 2=0.0000\end{array}$ \\
\hline Autocorrelation & $\begin{array}{l}\text { modified Bhargava et al. Durbin-Watson }= \\
.64393158 \\
\text { Baltagi-Wu LBI }=.97622635\end{array}$ \\
\hline $\begin{array}{l}\text { Interdivisional } \\
\text { correlation }\end{array}$ & $\begin{array}{l}\text { Pesaran's test of } \quad \text { cross sectional } \\
\text { independence }=1.327, \quad \operatorname{Pr}=0.1845\end{array}$ \\
\hline \multicolumn{2}{|c|}{ High income countries } \\
\hline Heteroscedasticity & $\begin{array}{l}\operatorname{chi} 2(43)=28851.37 \\
\text { Prob }>\text { chi } 2=0.0000\end{array}$ \\
\hline Autocorrelation & $\begin{array}{l}\text { modified Bhargava et al. Durbin-Watson = } \\
.72707414 \\
\text { Baltagi-Wu LBI }=1.1787816\end{array}$ \\
\hline $\begin{array}{l}\text { Interdivisional } \\
\text { correlation }\end{array}$ & $\begin{array}{l}\text { Pesaran's test of } \quad \text { cross } \quad \text { sectional } \\
\text { independence }=5.752, \quad \operatorname{Pr}=0.0000\end{array}$ \\
\hline
\end{tabular}

